\title{
Comments on A Multiscale Approach to Seagrass Recovery in Tampa Bay, Florida Greening et al. 2011-Ecological Restoration 29(1-2): 82-93.
}

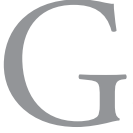
reening et al. (2011) mention 2 current objectives of the seagrass management program for Tampa Bay: 1) protect the current 12,000 ha of seagrass from damage and decline; and 2) restore an additional approximately 3,380 ha of seagrass in the Bay. Passing reference is made to a third objective that had to proceed these two, and that was the reduction in discharges of nutrients to Tampa Bay that along with other stressors had reduced seagrass cover to about 8,000 ha in 1982.
\end{abstract}

Several references are made (on pages 82 and 84-85) to this effort being led by the "research and restoration community" without appropriate reference in professional opinion to the summary by Lewis and others (1998) (senior author Greening was a co-author) describing in some detail the role of citizens and citizen led organizations that prodded the local political community to seek funding for a federal water quality study (Federal Water Pollution Control Administration 1969) and later matching funds ( $75 \%$ of the necessary $\$ 100$ million) from the U.S. Environmental Protection Agency to allow construction of an advanced waste water treatment facility that went into full operation in 1979.

The importance of this is that if someone desired to replicate the Tampa Bay success story with successful large scale seagrass restoration, one would need to realize that the effort started with local citizens concerned about the degradation of the Bay. It did not start with government realization of a problem and then government led action. This "bottom-up" approach is significant, as often "top-down" approaches do not involve the lay citizen, and therefore often do not have the necessary political support for major infrastructure expenditures, nor support from citizens to pay higher utility fees. All of this happened before the Tampa Bay National Estuary Program (TBNEP) (now the Tampa Bay Estuary Program-TBEP) came into existence in 1991.

Ecological Restoration Vol. 30, No. 1, 2012

ISSN 1522-4740 E-ISSN 1543-4079

C 2012 by the Board of Regents of the University of Wisconsin System.
I feel it is also important to note that recovery of seagrasses was first documented and reported by Roger Johansson then with the City of Tampa Bay Study Group and myself in 1992 (Johansson and Lewis 1992), another important milestone paper that is not referenced in Greening et al. (2011). This was the first documented recovery of seagrasses following active efforts to improve water quality in the world. This information was presented at the March 1990 Marine Coastal Eutrophication Conference in Bologna, Italy, and published in 1992, just $1 \mathrm{yr}$ after the formation of the TBNEP. The paper contained maps of seagrass distribution around Wolf Branch Creek in Middle Tampa Bay clearly documenting expansion of seagrasses (1984-1988) after water quality improvements, also documented in the paper.

None of the above is meant to diminish the important role of the TBNEP and the TBEP in working towards the "holding the line" nitrogen-loading strategy, a key program for seagrass protection and management going forward, but the Nitrogen Management Consortium was established in 1998. If one looks carefully at Figure 2 in Greening et al. (2011) and defines a pre-consortium period before 1998 and a post-consortium period after 1998, it is obvious that the vast majority of the area of seagrass recovery to date occurred before the consortium came into existence. It is my professional opinion, and that of my colleagues, that the majority, if not all, of this recovery can be attributed to advanced wastewater treatment and other nutrient abatement programs put in place before TBNEP came into existence. My main point here is that there were major citizen led efforts before TBNEP that led to water quality improvements and seagrass recovery that were documented by groups, such as the City of Tampa Bay Study Group and me, that should be appropriately cited to tell the whole story and allow readers to understand the complexity of these efforts, should they wish to duplicate them in other estuaries.

\section{References}

Federal Water Pollution Control Administration. 1969. Problems and management of water quality in Hillsborough Bay, 
Florida. Tampa, FL: Hillsborough Bay Technical Assistence Project.

Greening, H.S., L.M. Cross and T. Sherwood. 2011. A multiscale approach to seagrass recovery in Tampa Bay, Florida. Ecological Restoration 29(1-2):82-93.

Johansson, J.O.R. and R.R. Lewis. 1992. Recent improvements of water quality and biological indicators in Hillsborough Bay, a highly impacted subdivision of Tampa Bay, Florida, USA. Pages 1199-1215 in Proceedings of an International Conference on Marine Coastal Eutrophication, Bologna, Italy, 21-24 March 1990.
Lewis III, R.R., P.A. Clark, W.K. Fehring, H.S. Greening, R.O. Johansson and R.T. Paul. 1998. The rehabilitation of the Tampa Bay Estuary, Florida, USA, as an example of successful integrated coastal management. Marine Pollution Bulletin 37:468-473.

Roy R. Lewis III, Lewis Environmental Services, Inc., P.O. Box 5430, Salt Springs, Florida 32164-5430, lesrrl3@aol.com. 